\title{
Inventarisasi Ektoparasit pada Ikan Mas Koki (Carrasius auratus) Di Kecamatan Ciseeng - Kabupaten Bogor
}

\author{
Inventory of Ectoparasites on Goldfish (Carrasius auratus) \\ in District Ciseeng Bogor Regency
}

\author{
Samsi Haryono, Mulyana, Maria Angela Lusiastuti \\ Jurusan Perikanan, Fakultas Pertanian, Universitas Djuanda Bogor \\ E-mail: mulyanamarhalymsi@gmail.com
}

\begin{abstract}
This study aimed to identify and inventory the types and prevalence of ectoparasites on Goldfish (Carrasius auratus) that were cultivated in District Ciseeng Bogor Regency. The method used was to take a sample object as much as $10 \%$ of the total farmers Goldfish in Ciseeng District as many as 15 fish farmers scattered Parigi Mekar village, Babakan and Ciseeng. Each pool taken as much as 5 fish / pool, so the total samples analyzed were 75 fishes. Each fish will be observed in the slime, gills and fins and compared it using key book of parasite identification. From the results of research on Goldfish were derived from the District Ciseeng the types of ectoparasites that infested the fish as follows: Trichodina sp, Dactylogyrus sp, Gyrodactylus sp, Ichthyophthirius multifiliis, Argulus sp, Tetrahymena sp and Oodinium sp. The prevalence of ectoparasites on goldfish in District Ciseeng were: Trichodina sp (79\%), Dactylogyrus sp (25\%), Gyrodactylus sp (43\%), Ichthyophthirius multifiliis (7\%), Argulus sp (5\%), Tetrahymena sp (21\%) and Oodinium sp (24 $\%)$. The prevalence of ectoparasites according to village location were: Parigi Mekar Village (94\%), Village Babakan (95\%) and Village Ciseeng (95\%). The prevalence of ectoparasites from organs: mucus $(87 \%)$, the gills $(51 \%)$ and the fins $(53 \%)$.
\end{abstract}

Key words: goldfish, ectoparasites and inventory

\begin{abstract}
ABSTRAK
Penelitian ini bertujuan untuk mengidentifikasi dan inventarisasi jenis dan prevalensi ektoparasit pada ikan Mas Koki (Carrasius auratus) yang dibudidayakan di Kecamatan Ciseeng Kabupaten Bogor. Metode penelitian yang digunakan adalah dengan mengambil obyek sampel sebanyak 10\% dari total pembudidaya ikan Mas Koki di Kecamatan Ciseeng yaitu sebanyak 15 pembudidaya ikan yang tersebar di Desa Parigi Mekar, Babakan dan Ciseeng. Masing-masing kolam diambil sebanyak 5 ekor/kolam, sehingga total sampel yang diamati adalah 75 ekor. Masing-masing ikan akan diamati pada bagian lendir, insang dan sirip dan membandingkan hasilnya dengan buku kunci identifikasi parasit. Dari hasil penelitian terhadap ikan Mas Koki yang berasal dari Kecamatan Ciseeng didapatkan jenis-jenis ektoparasit yang menginfestasi ikan sebagai berikut: Trichodina sp, Dactylogyrus sp, Gyrodactylus sp, Ichthyophthirius multifiliis, Argulus sp, Tetrahymena sp dan Oodinium sp. Untuk prevalensi ektoparasit pada ikan Mas Koki di Kecamatan Ciseeng adalah: Trichodina sp (79\%), Dactylogyrus sp (25\%), Gyrodactylus sp (43\%), Ichthyophthirius multifiliis (7\%), Argulus sp (5\%), Tetrahymena sp (21\%) dan Oodinium sp (24\%). Adapun prevalensi ektoparasit pada masing-masing desa adalah: Desa Parigi Mekar (94\%), Desa Babakan (95\%), dan Desa Ciseeng (95\%). Prevalensi ektoparasit berdasarkan organ tubuh adalah: lendir (87\%), insang (51\%) dan sirip (53\%).
\end{abstract}

Kata kunci : ikan mas koki, ektoparasit, prevalensi

Haryono Mulyana Maria. 2016. Inventarisasi Ektoparasit pada Ikan Mas Koki (Carrasius auratus)di Kecamatan Ciseeng - Kabupaten Bogor. Jurnal Mina Sains 2(2): 71-79. 


\section{PENDAHULUAN}

Penyakit akibat infeksi parasit merupakan ancaman yang cukup serius dibandingkan dengan gangguan dari faktor lain. Parasit dapat menjadi wabah bila diikuti oleh sekunder lainnya. Wahid (2009) pada penelitiannya mengindentifikasi adanya bakteri Aeromonas hydrophila, Pseudomonas flourescens, Flexibacter columnaris dari luka pada ikan mas koki yang disebabkan oleh parasit jenis Argulus sp. Parasit ini sering menyerang ikan pada bagian sirip, kulit, insang dan seluruh bagian inangnya. Penyakit yang disebabkan oleh parasit ini dapat menyebabkan penurunan kualitas dan kuantitas produk yang berimplikasi pada kerugian ekonomi bagi pembudidayanya. Ikan-ikan yang terserang parasit biasanya mengalami kerusakan pada bagian tubuhnya, sehingga penampakan dari ikan tersebut menjadi jelek. Harga ikan hias salah satunya ditentukan oleh penampakan ikan tersebut, sehingga bila penampakan ikan tersebut jelek maka harganya akan jatuh juga.

Langkah pertama yang harus dilakukan untuk mengatasi penyakit yang menyerang ikan adalah mendeteksi tanda-tanda serangan dan mengindentifikasi secepat mungkin penyebabnya. Untuk upaya penanggulangan dan pemberantasan penyakit diperlukan informasi mengenai jenis patogen, jenis ikan yang terserang dan waktu kejadiaannya. Informasi ini sangat berguna untuk melakukan tindakan pencegahan serta pengobatan yang tepat dan efektif.

\section{METODE PENELITIAN}

\section{Waktu dan Tempat Penelitian}

Penelitian ini dilaksanakan pada bulan Januari - April 2015, bertempat di Instalasi Penelitian dan Pengembangan Pengendalian Penyakit Ikan Jalan Perikanan No.13A Pancoran Mas - Kota Depok, Jawa Barat.

\section{Alat dan Bahan Penelitian}

Ikan uji yang diteliti adalah benih ikan mas koki umur 7-14 hari yang berasal dari sentra budidaya ikan mas koki di Kecamatan
Ciseeng Kabupaten Bogor. Bahan-bahan lain yang akan digunakan dalam penelitian ini adalah akuades dan alkohol. Alat-alat yang akan digunakan dalam penelitian ini adalah mikroskop binokuler, pisau bedah/scalpel, papan bedah, gunting, pipet tetes, gelas piala, kaca obyek, kaca tutup, pinset, oven, corong gelas, buret, pinset, thermometer, spektrofotometer, dan $\mathrm{pH}$-meter.

\section{Metode Penelitian}

Metode yang dilakukan pada penelitian adalah sebagai berikut: mencari data ke Dinas Pertanian dan Perikanan Kota Depok untuk memperoleh data dan informasi tentang jumlah kelompok pembudidaya ikan mas koki di Kecamatan Ciseeng Kabupaten Bogor kemudian menentukan kelompok pembudidaya ikan sebagai tempat pengambilan sampel, dari jumlah data seluruh pembudidaya ikan mas koki, diambil $10 \%$ sebagai obyek pengambilan sampel. Pengambilan sampel ikan mas koki untuk di uji sebanyak 5 ekor/kolam/pembudidaya.

Untuk mengetahui jenis ektoparasit yang menginfeksi benih ikan hias neon tetra dan menentukan prevalensi tiap jenis ektoparasit, maka dilakukan pemeriksaan ektoparasit melalui preparat ulas basah menggunakan mikroskop binokuler dengan pembesaran $100 x-200 x$.

\section{Analisis Data}

Data yang didapatkan adalah jenis parasit ikan mas koki. Parasit yang ditemukan pada ikan mas koki didokumentasi menggunakan kamera digital. Pengolahan data dilakukan menggunakan Microsoft Excell. Data hasil identifikasi selanjutnya di analisis dengan menghitung prevalensinya. Prevalensi adalah persentase ikan yang terinfeksi parasit dari seluruh ikan yang diperiksa. Prevalensi dihitung dengan rumus sebagai berikut:

$$
\text { Prevalensi }=\frac{\sum \text { ikan yang terinfeksi }}{\sum \text { ikan yang diperiksa }} \times 100 \%
$$




\section{HASIL DAN PEMBAHASAN}

\section{Prevalensi Ektoparasit Pada Ikan Mas Koki}

Prevalensi ikan mas koki di Kecamatan Ciseeng yang terinfeksi ektoparasit dapat dilihat pada Tabel 1.

Tabel 1 Prevalensi Ektoparasit Pada Ikan Mas Koki di Berbagai Lokasi Sampling

\begin{tabular}{lccc}
\multirow{2}{*}{$\begin{array}{c}\text { Jenis } \\
\text { Ektoparasit }\end{array}$} & \multicolumn{3}{c}{ Prevalensi (\%) } \\
\cline { 2 - 4 } & Parigi Mekar & Babakan & Ciseeng \\
\hline Trichodina sp & $91 \%$ & $55 \%$ & $80 \%$ \\
Gyrodactylus sp & $43 \%$ & $40 \%$ & $45 \%$ \\
Dactylogyrus sp & $34 \%$ & $25 \%$ & $10 \%$ \\
Tetrahymena sp & $40 \%$ & 0 & $10 \%$ \\
$\begin{array}{l}\text { Ichthyophthirius } \\
\text { multifiliis }\end{array}$ & 0 & $25 \%$ & 0 \\
Argulus sp & $11 \%$ & 0 & 0 \\
Oodinium sp & $31 \%$ & $10 \%$ & $25 \%$ \\
\hline
\end{tabular}

Berdasarkan hasil di tabel 1 didapatkan bahwa prevalensi berdasarkan banyaknya jenis ektoparasit yang paling banyak menginfestasi adalah di Desa Parigi Mekar. Ada beberapa hal yang menyebabkan hal ini, diantaranya adalah para pembudidaya ikan mas koki di Desa Parigi Mekar kebanyakan menggunakan bibit yang berasal dari daerah lain. Sedangkan Desa Babakan dan Desa Ciseeng menggunakan bibit dari hasil pembenihan sendiri. Ikan yang berasal dari daerah lain tersebut memiliki peluang membawa bibit penyakit dari daerah asalnya. Peluang terbawanya parasit dari satu daerah ke daerah lain setelah mengalami adaptasi, mengakibatkan epizootik bagi ikan di lokasi yang baru (Trimariani et al. 1994). Selain bibit yang berasal dari luar, kondisi kolam tempat pemeliharaan ikan mas koki yang berada di Desa Parigi Mekar kebanyakan terbuka dan sangat dekat dengan saluran pembuangan rumah tangga, sehingga kolam sangat rentan terkontaminasi oleh air yang berasal dari luar dan dari limbah rumah tangga.

Dari jenis-jenis ektoparasit tersebut yang paling banyak menginfestasi ikan mas Koki adalah Trichodina sp. Tingginya infestasi Trichodhina sp dikarenakan parasit ini secara alami banyak ditemukan disemua perairan dan parasit ini juga relatif mudah berkembang di air yang tenang atau di kolam. Berdasarkan pengamatan dilapangan memang para pembudidaya ikan jarang sekali melakukan pergantian air dengan alasan menghindari pemakaian pompa air yang berlebihan yang dapat menyebabkan biaya operasional menjadi tinggi. Hal ini memudahkan parasit ini berkembang biak dengan pesat. Trichodina $\mathrm{sp}$ juga merupakan ektoparasit yang mempunyai pergerakan aktif, sehingga dengan adanya kontak antar ikan, akibat kepadatan yang tinggi, memungkinkan terjadinya penularan ektoparasit melalui kulit dengan cepat.

Trichodina sp adalah ektoparasit patogen yang biasa menyerang ikan air tawar. Parasit ini merupakan masalah utama dalam budidaya air tawar di Indonesia karena dapat menyebabkan kerugian ekonomis,pertumbuhan terhambat dan periode pemeliharaan lebih lama. Trichodina sp mempunyai peranan yang sangat besar terhadap budidaya ikan karena parasit ini dapat menurunkan daya tahan tubuh ikan dan menyebabkan terjadinya infeksi sekunder. Trichodina sp dalam jumlah sedikit tidak menyebabkan dampak serius, akan tetapi infeksi berat parasit ini akan menimbulkan luka terbuka pada tubuh luar ikan. Hal ini disebabkan karena Trichodina sp memiliki cincin dentikel berupa cakram yang berfungsi sebagai alat penempel. Parasit ini umumnya lebih bersifat komensalis daripada parasitik sejati, karena hanya memakan sel-sel kulit ikan yang mati. Namun karena sturktur alat penempel yang keras (chitin) sering mengakibatkan iritasi dan luka pada kulit sehingga menyebabkan masuknya infeksi sekunder oleh bakteri dan/atau cendawan. Bekas luka inilah yang akan menjadi jalan bagi masuknya sumber penyakit yang lain.

\section{Prevalensi Ektoparasit Pada Ikan Mas Koki Di Berbagai Ukuran}

Prevalensi ektoparasit berdasarkan ukuran tubuh ikan dapat dilihat pada Tabel 2. 
Tabel 2 Prevalensi Ektoparasit pada Ikan Mas Koki di Berbagai Ukuran

\begin{tabular}{lccc}
\hline \multirow{2}{*}{ Jenis Parasit } & \multicolumn{3}{c}{ Ukuran Ikan (Cm) } \\
\cline { 2 - 4 } & $<\mathbf{3 , 0}$ & $\mathbf{3 , 1 - 6 , 0}$ & $>\mathbf{6 , 1}$ \\
\hline Trichodina $\mathrm{sp}$ & 68 & 100 & 73 \\
Gyrodactylus $\mathrm{sp}$ & 50 & 29 & 50 \\
Dactylogyrus $\mathrm{sp}$ & 32 & 42 & 0 \\
Tetrahymena $\mathrm{sp}$ & 43 & 17 & 0 \\
Ichthyophthirius & 18 & 0 & 0 \\
multifiliis & 0 & 0 & 13 \\
Argulus $\mathrm{sp}$ & 50 & 17 & 0 \\
Oodinium $\mathrm{sp}$ & & & \\
\hline
\end{tabular}

Data yang diperoleh terkait hubungan antara ukuran tubuh ikan dengan ektoparasit yang menginfestasi ikan mas koki sebagaimana Tabel 2 menunjukkan bahwa jenis ektoparasit paling banyak menyerang pada ikan yang berukuran $<3,0 \mathrm{~cm}$. Jenis ektoparasit yang menginfestasi ikan ukuran ini adalah Trichodina sp, Dactylogyrus sp, Gyrodactylus sp, Tetrahymena sp, Ichtyophtirius multifiliis, dan Oodinium sp. Nugraha (2008) mengatakan bahwa penyakit disebabkan karena terjadi ketidakseimbangan antara inang, patogen dan lingkungan. Inang memiliki ketahanan tubuh (sistem imunitas) terhadap patogen dan lingkungan. Pada fase benih lebih rentan terserang penyakit terutama parasit. Ikan kecil memiliki respon antibodi yang lebih lambat daripada ikan yang memiliki umur dewasa. Hal ini disebabkan karena sistem imun pada hewan yang dewasa sudah terbentuk dengan sempurna, sehingga lebih tahan terhadap infeksi ektoparasit.

Pada ikan ukuran $3,1-6,0 \mathrm{~cm}$ jenis ektoparasit lebih sedikit dibanding ukuran sebelumnya. Pada ukuran ini jenis ektoparasit yang menginfestasi Trichodina sp, Dactylogyrus sp, Gyrodactylus sp, Tetrahymena sp dan Oodinium sp. Yang perlu diperhatikan pada ukuran ini prevalensi Trichodina sp mencapai 100 persen. Parasit Trichodina sp dapat menyebabkan stres dan dapat menyebabkan kerusakan pada morfologi ikan. Jika tingkat infeksi Trichodina sp tinggi serta didukung dengan kondisi perairan yang mendukung, maka akan mempercepat proses perkembangbiakan parasit ini.
Pada ukuran yang paling besar $(>6,1 \mathrm{~cm})$ jenis ektoparasit yang menginfestasi semakin sedikit. Hal ini disebabkan karena semakin dewasa sistem imun sudah terbentuk dengan sempurna. Jenis ektoparasit yang menyerang adalah Trichodina sp, Gyrodactylus sp dan Argulus sp.Jenis parasit yang hanya ditemukan pada ukuran ini adalah Argulus sp. Argulus sp menyerang ikan dengan menghisap darah, sehingga menyebabkan ikan stress, dan terjadi perubahan tingkah laku pada ikan mas koki tersebut. Perubahan tingkah laku pada ikan antara lain: berenang pasif dan selera makan menjadi turun. Hal ini terjadi karena infestasi Argulus sp yang menyerang ikan mas koki menimbulkan bekas luka akibat alat penghisap dari Argulus sp yang kemudian akan timbul ulcer, dalam jangka waktu yang agak lama akan terjadi pendarahan dan kerusakan jaringan pada bagian luar dari kulit ikan yang terserang Argulus sp tersebut.

\section{Prevalensi Ektoparasit di bagian Lendir, Insang dan Sirip}

Prevalensi ektoparasit berdasarkan bagian tubuh adalah: prevalensi ektoparasit pada lendir $87 \%$, insang $51 \%$ dan sirip $53 \%$. Adapun hasil pengamatan ektoparasit pada ikan mas koki berdasarkan organ yang terinfestasi sebagaimana Tabel 3.

Tabel 3 Prevalensi Ektoparasit di bagian Lendir, Insang dan Sirip

\begin{tabular}{lccc}
\hline \multicolumn{1}{c}{ Jenis } & \multicolumn{3}{c}{ Organ Target } \\
\cline { 2 - 4 } Ektoparasit & Lendir & Insang & Sirip \\
\hline Trichodina $\mathrm{sp}$ & 65 & 40 & 45 \\
Gyrodactylus $\mathrm{sp}$ & 27 & 4 & 29 \\
$\begin{array}{l}\text { Dactylogyrus } \mathrm{sp} \\
\text { Tetrahymena } \mathrm{sp}\end{array}$ & 0 & 25 & 0 \\
$\begin{array}{l}\text { Ichthyophthirius } \\
\text { multifiliis }\end{array}$ & 7 & 7 & 12 \\
$\begin{array}{l}\text { Argulus } \mathrm{sp} \\
\text { Oodinium } \mathrm{sp}\end{array}$ & 3 & 0 & 4 \\
\hline & 11 & 0 & 0 \\
\hline
\end{tabular}

Hasil pengamatan ektoparasit pada ikan mas koki berdasarkan organ yang terinfestasi sebagaimana Tabel 3 didapatkan jenis ektoparasit yang menginfestasi bagian lendir adalah Trichodina sp, Gyrodactylus sp, Tetrahymena sp, Ichtyophtirius multifiliis, Argulus sp dan Oodinium sp. Banyaknya jenis parasit yang menginfestasi bagian lendir ini 
wajar dikarenakan permukaan tubuh merupakan bagian yang pertama kali kontak dengan lingkungan. Dengan kata lain lendir dipermukaan tubuh merupakan jalan masuk bagi masuknya parasit ke dalam tubuh ikan.

Mulyana (2011) mengatakan kulit dan sisik ikan berperan dalam perlindungan mekanik terhadap invasi patogen melalui penebalan kutikula ataupun hiperflasia sel-sel malfigi. Reaksi peradangan juga dapat terjadi di sekitar situs masuknya patogen, dalam hal ini komponen lainnya yang berperan dalam proses pertahanan seluler seperti leukosit akan membanjiri situs untuk memfagosit patogen yang ada tersebut. Produksi lendir yang berlebihan pada kulit ikan ini dapat mengindikasikan bahwa ikan tersebut sedang terinfeksi parasit.

Pada bagian insang didapatkan jenis ektoparasit yang menginfestasi bagian insang adalah Trichodina sp, Dactylogyrus sp, Gyrodactylus sp, Tetrahymena sp, dan Oodinium sp. Pada bagian insang parasit jenis Dactylogyrus sp secara spesifik hanya menginfestasi bagian insang saja dan tidak ditemukan dibagian tubuh yang lain. Insang merupakan organ yang sangat vital pada ikan, karena insang sebagai alat pernafasan bagi ikan. Insang berbentuk lembaran lembaran tipis yang berwarna merah muda dan selalu lembab. Bagian terluar dari insang berhubungan dengan air, sedangkan bagian dalam berhubungan dengan kapiler-kapiler darah. Karena berhubungan dengan air, maka insang sangat mudah terinfeksi oleh parasit. Insang yang terinfeksi parasit dalam jumlah besar akan kelihatan berwarna pucat dan keputih-putihan atau membengkak sehingga operkulum terbuka. Kerusakan pada insang menyebabkan sulit bernafas, sehingga tampak megap-megap seperti gejala kekurangan oksigen. Insang ikan rusak, luka dan timbul perdarahan serta berlebihan lendir (stadium awal). Dalam keadaan serius filamen insang akan rusak dan operkulum ikan tidak tertutup dengan sempurna mengakibatkan kesulitan bernafas. Ikan sering terlihat mengumpul di sekitar air masuk, karena pada daerah ini kualitas air terutama kadar oksigen lebih tinggi. Selain itu ikan juga sering mengapung di permukaan air.
Organ lain yang diamati adalah bagian sirip, dimana jenis ektoparasit yang ditemukan adalah Trichodina sp, Gyrodactylus sp, Tetrahymena sp, Ichtyophtirius multifiliis dan Oodinium sp. Karena letaknya diluar dan kontak langsung dengan air, maka bagian ini juga sangat mudah terinfestasi oleh parasit. Sirip pada tubuh ikan mempunyai fungsi sebagai alat gerak dan keseimbangan. Apabila sirip ikan terinfestasi parasit pada jumlah besar akan menimbulkan kerusakan pada sirip sehingga dapat mengganggu pergerakan ikan. Ikan juga akan kelihatan berenang tidak tenang. Untuk ikan mas koki, kerusakan pada sirip sangat menimbulkan kerugian ekonomi karena sirip yang rusak menyebabkan harga jual ikan tersebut menjadi jatuh.

\section{Tanda-tanda akibat infeksi parasit pada Ikan Mas Koki}

Terhadap ikan-ikan sampel yang diambil dilakukan pengamatan tanda-tanda yang timbul akibat infeksi dari ektoparasit adalah sebagai berikut: produksi lendir yang berlebihan sehingga mengakibatkan ikan berwarna pucat, nafsu makan menurun, gelisah dan gerakannya lamban, menggosok-gosokan badan pada benda disekitarnya, sirip rusak bahkan rontok, untuk yang terserang Dactylogyrus sp ujungujung insang menjadi menebal dan operculum tampak terbuka, khusus Ichtyophtirius multifiliis ditandai bintik-bintik putih (white spot), untuk Argulus sp secara visual tampak seperti kutu yang menempel pada tubuh ikan dan disertai pendarahan disekitar tempat gigitannya, serangan Oodinium sp dikulit menyebabkan warna keemasan, berkarat atau putih kecoklatan atau kelihatan dekil.

\section{Kualitas Air}

Pada masing-masing lokasi budidaya di Kecamatan Ciseeng telah diukur parameter lingkungan berupa $\mathrm{pH}$, DO, Suhu dan NH3 dimana hasilnya ditampilkan pada Tabel 4. 
Tabel 4 Kualitas air kolam di masing-masing lokasi pengambilan sampel

\begin{tabular}{ccccc}
\hline $\begin{array}{c}\text { Kualitas } \\
\text { Air }\end{array}$ & $\begin{array}{c}\text { Desa } \\
\text { Parigi } \\
\text { Mekar }\end{array}$ & $\begin{array}{c}\text { Desa } \\
\text { Babakan }\end{array}$ & $\begin{array}{c}\text { Desa } \\
\text { Ciseeng }\end{array}$ & $\begin{array}{c}\text { Standar } \\
\text { Kualitas } \\
\text { Air }\end{array}$ \\
\hline Suhu $\left({ }^{\circ} \mathrm{C}\right)$ & $29-30,5$ & $28,6-31$ & $28,6-30,5$ & $25-30$ \\
& & & & \\
& & & & \\
pH & $6,9-9,91$ & $7,85-$ & $5,39-8,92$ & $6,5-9$ \\
& & 10,25 & & \\
& & & & \\
NH3 & $0,195-$ & $0,220-$ & $0,195-$ & $<1$ \\
DO & 0,292 & 0,417 & 0,89 & \\
& $4,85-8,44$ & $4,67-$ & $4,99-7,30$ & $\begin{array}{c}\text { Minimal } \\
5 \mathrm{mg} / 1\end{array}$ \\
\hline
\end{tabular}

Dari tabel tersebut untuk parameter suhu dan DO dalam kisaran normal, adapun $\mathrm{pH}$ dan $\mathrm{NH} 3$ cenderung tinggi. Untuk $\mathrm{pH}$ di Desa Babakan ada kolam yang mencapai angka 10,25. Hal ini harus mendapat perhatian serius karena $\mathrm{pH}$ sangat berpengaruh sekali terhadap pertumbuhan ikan dan pertumbuhan parasit. Angka $\mathrm{pH}$ yang tinggi tersebut tidak sampai menyebabkan kematian, karena ikan mas koki teruji sebagai ikan yang tangguh karena dapat bertahan hidup di air yang berkualitas buruk.

Kordi (2004) mengatakan derajat keasaman atau $\mathrm{pH}$ mempengaruhi tingkat kesuburan perairan karena memberi pengaruh terhadap kehidupan jasad renik. Perairan asam akan kurang produktif, malah dapat membunuh hewan budidaya, dimana pada $\mathrm{pH}$ rendah (keasaman yang tinggi) kandungan oksigen akan berkurang, sebagai akibatnya konsumsi oksigen menurun, aktifitas pernapasan naik dan selera makan akan berkurang. Hal yang sebaliknya terjadi pada suasana basa. Atas dasar ini maka usaha budidaya perairan akan berhasil baik dalam air dengan $\mathrm{pH}$ 6,5- 9,0 dan

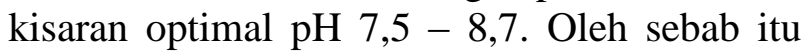
nilai $\mathrm{pH}$ suatu kolam budidaya harus tetap dijaga.

Berdasarkan pengamatan di lapangan, para pembudidaya ikan telah peduli terhadap kualitas air yang digunakan pada budidaya ikan mas Koki. Para pembudidaya ikan mas Koki di Kecamatan Ciseeng menggunakan daun ketapang pada kolam pembudidayaan.

Manfaat daun ketapang untuk mencegah dan mengobati penyakit pada budidaya ikan sudah diuji oleh beberapa peneliti. Hasil penelitian Wahyuningrum et al. (2008) menyebutkan bahwa daun ketapang berpotensi sebagai antibakteri yang dapat menghambat pertumbuhan bakteri A. hydrophila.

\section{KESIMPULAN DAN SARAN}

\section{Kesimpulan}

Kesimpulan dari hasil inventarisasi ektoparasit pada ikan mas koki (Carrasius auaratus) di Kecamatan Ciseeng didapatkan jenis ektoparasit yang menginfestasi ikan mas koki adalah Trichodina sp, Dactylogyrus sp, Gyrodactylus sp, Tetrahymena, Ichtyophtirius multifiliis, Argulus sp dan Oodinium sp. Adapun berdasarkan organ tubuh ikan, jenis ektoparasit yang ditemukan pada bagian lendir, insang dan sirip adalah: Trichodina $\mathrm{sp}$, Gyrodactylus sp, Tetrahymena, Ichtyophtirius multifiliis dan Oodinium sp. Jenis Dactylogyrus sp hanya ditemukan pada bagian insang saja. Sedangkan untuk jenis Argulus sp hanya ditemukan pada bagian lendir saja. Tanda-tanda yang timbul akibat infeksi dari ektoparasit adalah produksi lendir yang berlebihan sehingga mengakibatkan ikan berwarna pucat, nafsu makan menurun, gelisah dan gerakannya lamban, menggosok-gosokan badan pada benda disekitarnya, sirip rusak bahkan rontok, untuk yang terserang Dactylogyrus sp ujung-ujung insang menjadi menebal dan operculum tampak terbuka, khusus Ichtyophtirius multifiliis ditandai bintik-bintik putih (white spot), untuk Argulus sp secara visual tampak seperti kutu yang menempel pada tubuh ikan dan disertai pendarahan disekitar tempat gigitannya, serangan Oodinium sp dikulit menyebabkan warna keemasan, berkarat atau putih kecoklatan atau kelihatan dekil

\section{Saran}

Untuk melengkapi hasil inventarisasi ektoparasit pada ikan mas koki di Kecamatan Ciseeng perlu dilakukan juga terhadap induk ikan mas koki. Dengan hasil inventarisasi terhadap induk maka dapat dilakukan tindakan pencegahan agar tidak terjadi penularan dari induk kepada anaknya. 


\section{DAFTAR PUSTAKA}

Afrianto E, Liviawaty E. 1992. Pengendalian Hama dan Penyakit Ikan. Yogyakarta: Kanisius.

Afrianto E, Liviawaty E.2003. Mas Koki, Budidaya dan Pemasarannya. Yogyakarta: Kanisius.

Agus A. 1990. Maskoki. Jakarta: Penebar Swadaya.

Alifuddin M, Priyono A, Nurfatimah A. 2003. Parasit Pada Ikan Hias Air Tawar (Ikan Cupang, Gapi dan Rainbow). Jurnal Akuakultur Indonesia, 2 (2):93-100.

Alifuddin M, Priyono A, Nurfatimah A. 2002. Inventarisasi Parasit Pada Ikan Hias yang Dilalulintaskan di Bandara Soekarno Hatta, Cengkareng, Jakarta. Jurnal Akuakultur Indonesia, 1 (3):123-127.

Agromedia. 2008. Buku Pintar Ikan Hias Populer. Jakarta: Agromedia Pustaka.

Badan Pusat Statistik. 2013. Hasil Sensus Pertanian. http://www.bps.go.id. [20 Februari 2014].

Bachtiar Y. 2005. Mencegah Mas Koki Mudah Mati. Jakarta: Lentera.

Direktorat Jenderal Perikanan Budidaya. 2009. Buku Saku Pengendalian Penyakit Ikan. Jakarta: Kementerian Kelautan dan Perikanan

Effendie MI. 2002. Biologi Perikanan. Jakarta: Yayasan Pustaka Nusatama.

Effendi I. 2004. Pengantar Akuakultur. Jakarta: Penebar Swadaya

Ghufran M Kordi. 2009. Budi Daya Perairan. Buku Kedua. Bandung: Citra Aditya Bakti.

Hoffman GL. 1999. Parasits of North American freshwater fishes. NY: Cornell Univ. Press. 527 hal.
Humas Ditjen P2HP. 2013. Dokumentasi Kontes Ikan Mas Koki di Raiser Ikan Hias Cibinong. Jakarta: Kementerian Kelautan dan Perikanan.

Ilan Paperna. 1996. Parasites, Infections and Diseases of Fishes in Africa An update. http://www.fao.org/docrep/008. [ 9 Mei 2015].

Irawan. 2004. Budidaya Ikan Air Tawar: Ikan Gurame, Ikan Nila. Yogyakarta. Kanisius.

Irianto A. 2005. Patologi Ikan Teleostei. Yogyakarta. Gajah Mada University Press.

Jonathan A, Robert S, Martin W. 2006. Macronuclear Genome Sequence of The Ciliate Tetrahymena thermophila. Journal PBIO, California.

Kabata Z. 1969. Revision of the genus Salmincola Wilson, 1915 (Copepoda: Lernaeopodidae). J. Fish.Res. Board Can. 26: 2987-3047.

Kabata Z. 1988. Copepoda and Branchiura. Pac. Biolog. Stat., Nanaimo, British Columbia.

Kardi, Handayani R. 2013. Identifikasi dan Keragaman Ektoparasit Pada Ikan Maskoki (Carassius auratus) dan Ikan Mas (Cyprinus carpio) yang berasal dari Lampung dan Luar Lampung. Fakultas Pertanian, Universitas Lampung. http://digilib.unila.ac.id. [12 Januari 2014]

Khairuman. 2006. Budidaya Ikan Nila Secara Intensif. Depok: Agromedia Pustaka

Kordi MG. 2004. Penanggulangan Hama dan Penyakit Ikan. Jakarta: Rineka Cipta dan Bina Adiaksara.

Lom J, Dykova I. 1992. Protozoan parasites of fishes. Developments inaquaculture and fisheries science, vol. 26. Amsterdam: Elsevier Science Publishing Co. 
Noble, E. R, G.A. Noble, G. A. 1989. Parasitology L The Biology of Animal Parasites. Philadelphia, London: Lea and Febiger.

Noga EJ. 1988. Fish Disease: Diagnosis and treatment. Departement of Companion. Animal and Spesial Spesies Medecine, North Carolina University. North Carolina.

Nurleli. 2011. Budidaya Ikan Hias Air Tawar Ikan Mas Koki (Carrasius auratus). Badan Pengembangan SDM Kelautan dan Perikanan. Jakarta: Kementerian Kelautan dan Perikanan.

Nugraha, M. 2008. Derajat Infeksi Argulus sp pada Ikan Mas Koki (Cyprinus carpio) di Desa Bangoan, Tulungagung. Tugas Akhir. Fakultas MIPA. ITS.

Mulyana. 2010. Parasit dan Penyakit Ikan. Buku Ajar. Bogor: Unida Press.

Peritrich. 2014. Trichodina. https://fishpathogens.net/pathogen/trichodi na [9 Mei 2015].

Ratna Mariyana. 2013. Pertumbuhan Populasi Cacing Tanah (Pheretima sp) Sebagai Sumber Protein Pakan Ikan dalam Media Kotoran Kambing dengan Tiga Pakan Tambahan (Bungkil Sawit, Dedak dan Limbah Sayuran Pasar [Skripsi]. Bogor: Fakultas Ilmu dan Bisnis Pertania, Universitas Djuanda

Redaksi Agromedia. 2008. Buku Pintar Ikan Hias Populer. Jakarta: Agromedia Pustaka.

Peraturan Pemerintah Nomor. 82 Tahun 2001 Tentang Pengelolaan Kualitas Air dan Pengendalian Pencemaran Air.

Rohmat M. 2002. Inventarisasi Parasit Pada Ikan Maanvis, Ikan Mas Koki, Ikan Black Ghost dan Ikan Neon Tetra Di Daerah Jakarta Selatan, DKI Jakarta Skripsi (Skripsi). Bogor: Fakultas Perikanan dan Ilmu Kelautan, IPB.
Schell SC. 1985. Handbook of Trematodes of North America, North of Mexico. Moscow: Univ. Press of Idaho.

Sugiarti. 1997. Teknik Pembenihan Ikan Mujair dan Nila. Jakarta: CV. Simpleks.

Suwignyo S, Widigdo B, Wardianto Y. 1997. Avertebrata Air. Jilid 1. Bogor: Fakultas Perikanan, IPB.

Supian E. 2014. Penanggulangan Hama dan Penyakit Pada Ikan. Yogyakarta : Pustaka Baru Press.

Supriyadi H. 2009. Membuat Ikan Hias Tampil Sehat dan Prima. Jakarta: Agromedia Pustaka.

Trimariani A, Bahrudin A, Rustikawati I, Ristika R. 1994.Prevalensi Zooparasit pada Ikan Mas (Cyprinus Carpio) yang dipelihara dalam Jaring Apung di Bandung Cirata Jawa Barat. Jatinangor. Laporan Penelitian. Universitas Padjajaran.

The Freswater life Team. 2009. Protozoa / Ichthyophthirius multifiliis. http://www.freshwaterlife.org/imagearchie [20 Mei 2015]

Wahid Y N. 2009. Isolasi dan Identifikasi Bakteri Gram Negatif pada Luka Ikan Maskoki (Carassius auratus) akibat Infestasi Ekstoparasit Argulus sp [Skripsi]. Surabaya: Fakultas Perikanan dan Kelautan, Universitas Airlangga Surabaya.

Wahyuningrum D, Ashry N, Nuryati S. 2008. Pemanfaatan Ekstrak daun Ketapang Terminalia cattapa Untuk Pencegahan dan Pengobatan Ikan Patin Pangasionodon hypophthalmus yang Terinfeksi Aeromonas hydrophila. Bogor. Jurnal Akuakultur Indonesia, (7-1).

Watson, J. D, Baker, T. A, Bell, S.P, Gann A. 2004. Molecular Biology of the Gene. Edisi ke-2. Cold Spring Harbor Press. USA. 
Zheila NPR. 2013. Prevalensi dan Itensitas

Trichodina sp pada Benih Ikan Nila

(Oreochromis niloticus) di Desa

Tambakrejo Kecamatan Pacitan

Kabupaten Pacitan. Surabaya: Fakultas

Matematika dan Ilmu Pengetahuan Alam,

ITS. 